\title{
Investigating the Impact of Mnemonic-based Instruction on Saudi University Students' Attitudes Towards Vocabulary Learning
}

\author{
Waleed Othman, "Ph.D. Candidate" (Corresponding author) \\ Instructor of English, Head of Language Support Unit, ELC, Taibah University \\ Janadah Bin Umayyah Road, PO Box 344, Medina 42353, Saudi Arabia
}

Tel: 966 (50 943 0231) - (54 486 7902)Ｅ-mail: celtaholder1@gmail.com

Osama Mohammed, "Ph.D. Candidate"

Instructor of English, Head of Quality Dept., ELC, Taibah University

Janadah Bin Umayyah Road, PO Box 344, Medina 42353, Saudi Arabia

Tel: 966 (50282 2711) - (54 988 6718) E-mail: omohammed@taibahu.edu.sa

Bakare Kazeem Kayode “Asst. Prof.”

Faculty of Education, Al-Madinah International University (MEDIU)

E/9E 2, Jalan Tengku Ampuan Zabedah 40100, Shah Alam, Selangor, Malaysia

Tel: 60355113939 - Ext: 282 E-mail: bakare.kazeem@mediu.edu.my

Received: August 1, 2019 Accepted: August 22, 2019 Published: August 26, 2019

doi:10.5296/ijele.v7i2.15339 URL: https://doi.org/10.5296/ijele.v7i2.15339

\begin{abstract}
Vocabulary learning plays an essential role in foreign language learning. It is also central to language teaching and is of paramount importance to a language learner. Mnemonic is a technique that is used to instruct vocabulary and it helps learners remember better. The association of images and sounds with mnemonics can make it more powerful and effective to help language learners remember better and for a longer time, this can be achieved through applying a method called the keyword method. This study was designed to investigate university Saudi students' attitudes towards the mnemonic keyword method. By employing a survey research design to discover the attitudes of the students enrolled in the preparatory
\end{abstract}




\section{Macrothink}

year program at Taibah University. A questionnaire about 'Students' Attitudes towards Keyword Method (SAKM) having four Likert scales was used as an instrument for data collection from a sample of 40 students. Descriptive statistics (mean, median, mode, standard deviation.) and independent-sample t-test were exploited to analyze the data. The results of the study showed that Saudi students have positive attitudes towards the mnemonic keyword method that was used to instruct vocabulary.

Keywords: Mnemonic Keyword Method, Attitudes, teaching \& learning ESL/EFL vocabulary 


\section{Introduction}

To develop EFL learners' attitudes towards learning is regarded to be one of the most important issues that should be taken into account when exploring factors that impact the process of teaching-learning. Winne and Marx (1989) explain that motivation and attitude are two conditions for, and causes of effective and successful instruction. Thus, studies were carried out in several educational fields to investigate methods and strategies that could open the door to developing students' attitudes towards learning. Attitudes can be considered as a learned tendency to give a positive or negative response towards a specific object, person, idea, situation, etc.

The Longman Dictionary of Applied Linguistics and Language Teaching (2002, p.297) defines language attitudes as: "the attitudes which speakers of different languages or language varieties have towards each other's languages or to their own language. Expressions of positive or negative feelings towards a language may reflect impressions of linguistic difficulty or simplicity, ease or difficulty of learning, degree of importance, elegance, social status, etc. Attitudes towards a language may also show what people feel about the speakers of that language.

Language attitudes may have an effect on second language or foreign language learning. The measurement of language attitudes provides information which is useful in language teaching and language learning." As for education, Brown (2000) notes that teachers should recognize that all students possess positive and negative attitudes in varying degrees, and adds that the negative attitudes can be changed by thoughtful instructional methods, such as using materials and activities that help students achieve an understanding and appreciation of foreign culture, a fact that might be reflected in the process of learning the foreign language. Thus, attitudes could highly influence how individuals approach many situations in life, including foreign language learning. It is believed that individuals with positive attitudes usually progress more rapidly in foreign language learning.

Acquiring vocabulary is an essential factor in the process of successful language learning. The acquisition of lexical items plays a crucial role in mastering other skills such as listening, speaking, reading and writing. In addition, lack of vocabulary knowledge is the main obstacle for L 2 learning. Limited vocabulary in a second language impedes successful communication. Schmitt emphasizes that "lexical knowledge is central to communicative competence and to the acquisition of a second language" (2000, P. 55). Paribakht and Wesche (1999) noted that vocabulary acquisition was an incremental process that included the integration of several aspects and types of knowledge in combination with new skills to make use of that knowledge in communication. Vocabulary is grasped as the basic component of language proficiency, which provides the basis for students' performance in all English learning skills. Getting much vocabulary is better because they will have a stronger base in the learning process (Ummah et al., 2018).

Some instructors may contend that the vocabulary teaching techniques used are suitable and convenient, but when the students themselves are consulted, it is found that the opposite is true. 
Many students comment that learning new lexical items has always been challenging for them. Milton (2009) assures that the study of vocabulary has become much more 'fashionable,' particularly at 'an academic level.' Add to this, this importance has transferred itself to the mainstream front of foreign language teaching. Methods and techniques that aim to make students recall vocabulary deserve to be researched to investigate their impact on students' attitudes towards them. Lewis and Hill (1990) believe that using pictures, real objects and synonyms, miming, defining, exemplifying and translation are the seven common techniques of teaching vocabulary. Lewis (1999), contends that attitudes, time, depth of processing are factors that affect the retrieval and recall processes of the memory. There is a need for expanding the body of experimental studies to address several key questions about the effectiveness of different strategies and techniques of L2 vocabulary instruction on learning and retention (Tavakoli and Gerami, 2013).

The literature mentions that there is a group of techniques and strategies that can be effective in storing and retrieving data from human memory. They are called mnemonics. A mnemonic is "any procedure or operation designed to improve one's memory" (Scruggs et al., 2010, p. 79). According to Edublox (2017), mnemonics are memory aiding techniques which were first credited to Simonides of Ceos, a Greek Poet. One of those techniques for memorizing L2 vocabulary items that has received a great deal of attention is the mnemonic keyword method. It was firstly described by Atkinson (1975). This technique works by associating between the target L2 word and an L1'equivalent' in the form of a mediating 'keyword'. Mnemonic instruction links new information to prior knowledge using visual and/or acrostic cues (Akinsola \& Odeyemi, 2014). The use of such a method can better the students' retention of vocabulary. Mnemonics strategies are highly recommended to enhance the student's ability to memorize and keyword strategy is one of the paramount mnemonics strategies (Al-Khawaldeh, \& Al-Khasawneh, 2019). Sagarra \& Alba (2006) assert that the reason for drilling students on mnemonics is to enhance students' ability in remembering or acquiring new words.

\subsection{Background of the Study}

All Saudi universities have a Preparatory Year program to help bridge the gap between the public-school system and the undergraduate system (Yushau, \& Omar, 2007). The main goal of a Preparatory Year program is to enhance the knowledge and skills of secondary school graduates before they go through their chosen majors at university (Alshammari et al., 2018). They are also offered a convenient atmosphere that allows students to settle into the new university learning environment. Students are expected to develop knowledge and skills across a range of subjects to prepare them for the world of university. Proficiency in English is one of these skills. Their age ranges between 17 and 23 according to the university admission department. The researcher made sure that the respondents of the study are of that age limit.

There may also be some differences in Saudi students' educational experiences that are based on their gender. In all educational stages, Saudi Arabia's educational system is segregated on the basis of religion and other powerful cultural factors, and it is clear that this segregated milieu is having its negative effect on Saudi Arabia's ability to educate its population because 
it is contributing to the shortage of instructors, leading to, in at least some places, limits on some courses (Alanazy, 2013).

\subsection{Statement of the Problem}

Vocabulary knowledge is a central component of academic success and plays an essential role in forming learners' four language skills. Many EFL students, including the Saudi students, find it difficult to learn vocabulary which is, in many cases, is reflected in their poor communication, both verbally and in writing. The main issue is EFL Saudi learners know that they are in need to increase their vocabulary stock immensely; however, they may lack the tool and strategies that can assist them to be successful vocabulary learners and as a result, be successful language learners in general.

Another very remarkable issue is that many Saudi EFL learners have complaints that they forget most of the words they have learned. In order to find a solution to this problem, various techniques can be utilized to assist students to memorize vocabulary. One of them is using mnemonics, which is the focal point of this study.

\subsection{Research Objective}

The main objective of this quantitative study is to uncover the attitudes of tertiary students towards learning English vocabulary through the mnemonic keyword method. The current study, therefore, is an attempt to measure students' attitudes, either positive or negative towards this mnemonic method for teaching vocabulary.

\subsection{Questions of the Study}

The problem addressed by this study can be demonstrated in the different attitudes of university students towards learning EFL. Accordingly, the current study attempts to answer the following question:

- What are the attitudes of Taibah University students (The preparatory year) towards learning EFL vocabulary through the mnemonic keyword method?

\subsection{Limitations of the Study}

There are some limitations regarding some issue in the study. The sample size is not that big. The sample selection method is also can be considered a limitation. There is also a lack of data about the students as the researcher could not get enough data about the respondents' educational history. There is also the lack of resources of data about this topic in the Arab World and the Middle East.

\section{Literature Review}

2.1 Vocabulary LearningVocabulary is regarded as a crucial part of language learning. In this vein, Nation (2001) contends that there is a complementary relationship between language use and vocabulary knowledge. Solid vocabulary knowledge could certainly lead to fair performance in learning the language. Mastering vocabulary is an important feature of learning a foreign language. Communicating in a foreign language appears to be a 
complicated process if students have insufficient knowledge of vocabulary. Lacking particular vocabulary knowledge will negatively influence learners ${ }^{\text {ee }}$ production and comprehension of the target language (TL) and therefore learners will lose a tool of communication (Bahanshal, 2015). For that reason, language instructors are very attentive to vocabulary learning and the way it is presented.

Vocabulary acquisition needs more time and effort. Additionally, the frequent occurrences of vocabulary, as well as the vocabulary size, have an important impact on vocabulary acquisition (Laufer \& Hill, 2000). When tracking the history of teaching vocabulary, a number of techniques and strategies have been exploited to help students comprehend and recall new words. Many methodology scholars tried to come up with the best instructional procedures that lead to more effective vocabulary learning and achievement in a second or foreign language (Marzban and Firoozjahantigh, 2018). One of these various methods is mnemonics.

Mnemonic techniques are tools that simplify learning and remembering a lot of data that are not easy to remember. To make this education permanently memorable, use of strategies that consist of memory supportive in the learning process are suggested (Fulk, 2000; Scruggs \& Mastropieri, 2000). Mastropieri and Scruggs (1998) articulate that there are many other techniques like concentration, keeping notes, increasing the significance level, using pictures, preventing mixing, increasing the participation, enabling students to think and commenting on the subject and increasing the number of repetition. They can also be of great help to store the information but they do not particularly target learners to recall new information that they often do not succeed to learn and remember. In this respect, mnemonic methods can help in learning new and unusual information. Learners can learn faster and recall better with retrieval cues such as pictures of word meaning or personal experience of the underlying concept (Huong, 2018).

Mnemonic strategies help the students to link between their previous knowledge and the new information they obtain. They provide clues for students to recall data on a later on stage through providing criteria for information storage and retrieval of memory supplements (Ormrod, 1990). The mnemonic technique is a method that was proven to be very efficient in assisting learners to recall things (Dianitasari, 2019). Mnemonic strategies are categorized into two main parts as visual and verbal. Verbal memory supplements are about adjusting initials and creating rhymes but visual memory supplements are used with visual images like placement method, chaining method, word method of suspension and keyword method (Senemoğlu, 1997). Teachers may develop mnemonic techniques or have students come up with their own (Fasih et al., 2018). Mnemonic strategies had been used in different branches and in instructing various types of information proving their effectiveness in the findings of many studies.

Through these studies it is noticed that there are different usages of different mnemonic techniques (Carney and Levin, 2000; Franke, Levin and Carney 1991; Dretzke and Levin, 1990; Olçum, 2000; Rummel, Levin and Woodward, 2003; Carney and Levin, 2003; Stephens and Dwyer, 1997; Carney, Levin and Stackhouse, 1997; Uberti, Scruggs and Mastropieri 2003). 


\section{\لMacrothink}

Keyword method is a mnemonic strategy that was developed by Atkinson in 1975. This method divides vocabulary learning into two stages. The first stage requires the students to link the spoken form of the new L2 word with an acoustically similar first language (L1) word which is called the keyword. But in this study, the researcher used keywords from the same language; English. After the sound connection is formed, the second stage necessitates the learner to make a mental image to associate the meaning of the keyword and the meaning of the targeted word. The keyword method can be demonstrated as a sequence of two links connecting a new foreign word to the keyword (see Figure 1).

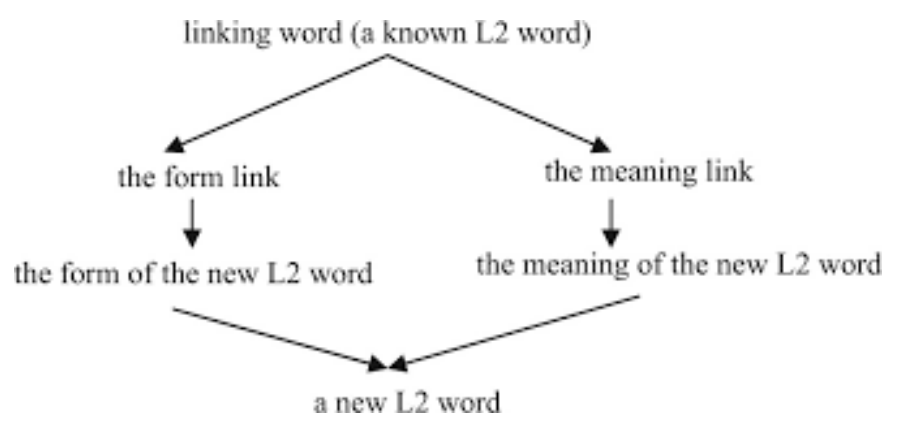

Figure 1. Two stages of the keyword method

The keyword method has attracted a great deal of attention in the area of language acquisition research. To seek evidence for proving the efficacy of the keyword method in comparison with other various vocabulary learning techniques, researchers have compared its effect with the effect of other learning strategies. It has been found to be super and superior to learning a lexical item in context (Brown \& Perry, 1991; Moore \& Surber, 1992; Rodriguez and Sadoski, 2000), rote learning (Al-Lahham, 2016; Sagarra \& Alba, 2006), imaging the meaning of the word (Pressley, Levin, Kuiper, Bryant, \& Michener, 1982) and semantic mapping (Sagarra\& Alba, 2006).

\subsection{Researching Keyword}

The keyword method was first demonstrated by Atkinson (1975) and later on examined on the American university students learning Russian vocabulary items (Atkinson and Raugh, 1975) and Spanish lexical items (Raugh and

Atkinson, 1975). The findings of both studies that used the keyword method were very effective and important and that prompted other various studies to be conducted. Amazingly, their results conformed to the initial results of both studies.

Pressley et al. contend that the method appeared to be effective for learning vocabulary and the results showed that it outperformed other learning strategies (1982).

A major problem facing the earlier studies of keyword methods was that they were conducted in laboratory conditions and the respondents were not real language students (Cohen, 1987). Thus, the findings of these studies were not of that significant as they do not have practical value. However, Merry (1980) did a study that demonstrates that the same effective results 
can be attained through classroom school conditions. This study proved the positive impact of the keyword method on both short-term and long-term retention of 11-year-old British students learning French in London.

\subsection{Theoretical Underpinnings}

The overarching goal of the science of education research is to improve the quality of science instruction and foster students' learning about science. In fact, the aim of the research is to promote knowledge and the powerfulness of that contribution to the field of research relies basically on the strength of the rationale provided for the methodology used. Through justification of the selected methodology as matched to the research questions, the credibility of the research can be strengthened (Sikes, 2004). An awareness of the philosophical underpinning for the research can 'secure the quality of the research produced' (Snape and Spencer, 2003, p. 3). Pring (2000, p. 89) contends that 'without the explicit formulation of the philosophical background - with implications for verification, explanation, knowledge of reality - researchers may remain innocently unaware of the deeper meaning and commitments of what they say or how they conduct their research'.

Wilson and Stutchbury (2009, p. 57) view that 'philosophical ideas often remain largely hidden' and, as such, research rigor can be strengthened by the researcher making transparent the philosophy that underpins the justification of their research methodology.

Empirically, there are various studies that offer evidence for the efficacy of the keyword method. Many theoretical rationales have been provided to support and justify the effectiveness of the mnemonic keyword method. One such rationale is Paivio's "Dual Coding Theory" (1991) in which he demonstrates that the keyword method employs twos routes to help the mind recall the lexical elements. These two routes are verbal and visual. They can be of great help to the memory to retrieve vocabulary.

The Dual Coding theory supposes that there are two cognitive subsystems, one specialized for the processing of nonverbal objects or events (pictures), and the other specialized for handling language (Acoustic). Paivio also posits that there are two different types of representational units: "imagens" for mental pictures and "logogens" for verbal entities. This theory identified three types of processing: (1) representational, the direct activation of verbal or non-verbal representations, (2) referential, the activation of the verbal system by the nonverbal system or vice-versa, and (3) associative processing, the activation of representations within the same verbal or nonverbal system. A given task may require any or all of the three kinds of processing. The main principle of this theory is retention of data is enhanced by introducing data in both nonverbal visual and verbal shape.

\subsection{Attitudes}

Saidat (2010) contends that during the last two decades, research on attitudes has expanded holding in view the language use and individual nature of learners, which are associated to a great extent. Recent research has explored the role of attitude towards learning a foreign language across the world having varied mixed cultures and different language backgrounds. In fact, emotions and memory are closely interlinked (Vlasceanu,2018). An example of this is a study by Shams (2008) who examined students' English language learning attitudes, 
anxiety and motivation. The results showed that the learners had positive attitudes towards English language learning which confirmed that English is of great importance to them. Massri (2017) examined the attitudes of Saudi EFL tertiary learners with a view to understanding the role of student attitudes in the effectiveness of EFL learning. Some of the prominent findings in this research include support for the earlier research suggesting the instrumental nature of Arab EFL language learner motivation and the identification of a number of factors of influence ranging from family obligations and/or pressure, financial implications as well as higher education achievements and travel/study abroad upon EFL learning in the KSA context. Saudi Students" attitudes towards E-learning were investigated and the participants reported having a positive attitude toward e-learning (Alsayyali, 2018). Attitudes are crucial in language growth or decay and restoration or destruction, they are the internal states that influence what the learners are likely to do (Alsamadani and Ibnian, 2015). When discussing factors that affect the teaching-learning process, developing the learners' attitudes towards the learning process is one of those factors that should be considered.

In the same vein, Winne and Marx (1989) state that attitude and motivation are both conditions and results of effective instruction. Thus, studies were conducted in different educational fields to investigate strategies and techniques that could help in developing learners' attitudes towards the learning process.

Attitudes can be regarded as a tendency to give a positive or negative response towards a certain thing, idea, situation, person, etc. This goes hand in hand with Kara (2009) who confirms that attitudes towards learning besides beliefs and opinions have a clear impact on students' behavior and as a result of their competence. It is believed that students who have more positive perceptions about language learning are also more likely to have more positive attitudes that would improve language learning.

Gardener (1985) puts his definition for attitudes as an evaluative reaction to some referent, inferred on the basis of the individual's beliefs or opinions about the referent. Brown (2000) explains that instructors should know that all students possess positive and negative attitudes in varying degrees, and adds that the negative attitudes can be altered by thoughtful instructional methods, such as using materials and activities that would be helpful to learners to accomplish an understanding and appreciation of foreign culture. This fact might be reflected in the process of learning a foreign language.

\subsection{Delimitations}

1- The study was confined to revealing students' attitudes towards the mnemonic keyword method.

2- The study was confined to revealing attitudes of students at one class in the preparatory year of Taibah University / Abyar Ali branch, towards the keyword method.

3- The study was conducted in the second term of the academic year 2018- 2019.

4- Dealing with the attitudes towards the keyword method is an important issue to tackle but there are other related problems that could have been chosen but were screened off from view. 
5- The study was conducted in the second term of the academic year 2018- 2019 is also considered a delimitation as it may have been conducted in the first term or the summer term. However, this would not have its impact on students as the environment in each semester is different due to the change of books, the rotation of instructors and the redistribution of the students. So the element of bias is diminished among students.

\section{Methodology}

3.1 The StudyThis study aims to examine the impact of the mnemonic keyword method on learning L 2 vocabulary. The study investigates the students' attitudes towards using the visual and acoustic elements as mnemonics in learning vocabulary.

\subsection{Respondents}

The participants for this study were 30 freshmen students. Those students were studying one-year compulsory English preparatory courses at the preparatory year before starting to take their major-area courses. These students graduated from high school and were 18 years of age or older.The participants in this study were students in the preparatory year at Taibah University in Al-Madinah Al-Munawarah in Saudi Arabia. Their native language is Arabic. They were selected randomly to participate in the study based on their willingness to participate. All of the respondents" answers were included, and no single response was excluded.

Table 1. Case Processing Summary

\begin{tabular}{|c|c|c|c|}
\hline \multirow{2}{*}{} & & $\mathrm{N}$ & $\%$ \\
\hline \multirow{3}{*}{ Cases } & Valid & 31 & 100.0 \\
\cline { 2 - 4 } & Excluded $^{\mathrm{a}}$ & 0 & .0 \\
\cline { 2 - 4 } & Total & 31 & 100.0 \\
\hline
\end{tabular}

a. Listwise deletion based on all variables in the procedure.

\subsection{Instruments}

\subsubsection{Questionnaire}

A close-ended questionnaire (see Appendix A) was conducted in order to examine the learners' perceptions about using the mnemonic keyword method for vocabulary learning. The questionnaire consisted of 6 statements. A paper questionnaire was distributed by the teacher. The questionnaire was adapted by the researcher and inspired by the literature specifically ((Mahdi and Gubeily, 2018). The researcher's adaption was due to the great similarity in the respondents' background and study context between both studies. In order to answer the research questions and to ensure accurate responses, the questionnaire was translated into Arabic as it is the students' native language (Arabic). Furthermore, both the English version and the translated version were checked for accuracy by three colleagues of 
the researcher, who were Arabic native speakers also fluent in English. The questionnaire exploited Likert five-point scale $(1=$ strongly disagree, $2=$ disagree, $3=$ neutral, $4=$ agree, and $5=$ strongly agree). The teacher explained how to use the

Likert scale and instructed students that writing their names on their surveys was optional. Walonick (1993) says that a questionnaire is used as it is cost-effective. Additionally, most statistical analysis software can be utilized to treat and process the data that is received from it (Walonick, 1993).

The questionnaire items were checked by two experts in TESOL to assess its content validity. The questionnaire reliability was checked by exploiting Cronbach's Alpha test. The result was. 0.715 as in the following table:

Table 2. Reliability Statistics

\begin{tabular}{|c|c|}
\hline $\begin{array}{c}\text { Cronbach's } \\
\text { Alpha }\end{array}$ & N of Items \\
\hline .715 & 8 \\
\hline
\end{tabular}

The high value of Cronbach's Alpha was ascribed to the few questionnaire items (i.e. six statements) of the questionnaire, therefore this number is acceptable.

\subsubsection{The Materials}

A range of materials has been employed during the experiment. The words have been chosen meticulously according to the level of students. This program consists of some themes and topics from the preparatory year English coursebook 'Q Skills 1'. It includes two units from the textbook. The design of the keywords is the core process in this program. The way to use the Keyword Method is through mixing substitute words with visualization which happens in a two-step process. First, keywords can be made using similar sounding words, or words that rhyme.

After the keyword is pinpointed, the students associate those concepts with an image representing the actual meaning of the word. However, there are many considerations that were kept in mind. Two elements are considered in selecting the keywords; visual and acoustic.

\subsection{Procedures}

Keeping in mind the principles of the mnemonic keyword method, the researcher designed the program based on the vocabulary in the Q Skills Reading and Writing book. This Cambridge English Course is studied by Saudi students in the preparatory year at Taibah University. The researcher tailored some lessons using the keyword method then explained to the students in the regular English vocabulary classes.

In order to answer the questions of the study, the researcher:

1 - Reviewed the related literature in the field of attitudes towards the keyword method. 
2 - Designed a questionnaire to measure students' attitudes towards the keyword method.

3 - Offered the questionnaire to specialized experienced ESL instructors to ensure its validity.

4 - Ensured the reliability of the questionnaire.

5 - Administered the attitudes questionnaire to the sample.

7 - Gathered and analyzed the data.

9 - Discussed the findings of the study.

10 - Submitted recommendations and suggestions for further research

\subsection{Analysis of the Data}

In order to explore the participants' attitudes of the effect of the keyword method, data gathered by the research tool (questionnaire) were coded and analyzed using SPSS (Statistical Package for Social Sciences), version 15.0 for Windows. The responses to the questionnaire were coded and calculated. The mean and standard deviation techniques were exploited to show how respondents consider learning vocabulary using the mnemonic keyword method.

\section{Results}

4.1 Research QuestionThe first research question is: What are the attitudes of Taibah University students (The preparatory year) towards learning EFL vocabulary through the mnemonic keyword method?

To answer this question, descriptive statistics were acquired to decide students' mean attitudes towards learning vocabulary through the keyword method.

Table 3. Item Statistics

\begin{tabular}{|c|c|c|c|}
\hline & Mean & Std. Deviation & $\mathrm{N}$ \\
\hline $\mathrm{x} 1$ & 4.9032 & .30054 & 31 \\
\hline $\mathrm{x} 2$ & 4.5806 & .50161 & 31 \\
\hline $\mathrm{x} 3$ & 4.1290 & .88476 & 31 \\
\hline $\mathrm{x} 4$ & 3.1613 & 1.34404 & 31 \\
\hline $\mathrm{x} 5$ & 4.1290 & .88476 & 31 \\
\hline $\mathrm{x} 6$ & 3.7097 & .58842 & 31 \\
\hline $\mathrm{x} 7$ & 3.3871 & .91933 & 31 \\
\hline $\mathrm{x} 8$ & 3.4516 & .99461 & 31 \\
\hline Total & 3.9314 & 0.4493 & 31 \\
\hline
\end{tabular}


Table 3 shows that students' mean attitude is 3.93 which falls in the "Mid" category and the standard deviation is 0.44 . This shows that they have a very positive response to the mnemonic keyword method. The results as shown in Table 3 show that most of the students felt that learning vocabulary was a very significant aspect of learning the English language. They truly believe that their vocabulary is in need to be enhanced and improved.

A great deal of the students contend they are able to enhance their vocabulary retention when using the keyword method. A great number of the subjects had the feeling that that mixing words and images caught their attention and interest to learn new lexical items which in turn led them to remember vocabulary in a better than any other traditional ways. Not a small number of respondents contend that the keyword method is more successful in helping students recall vocabulary than other conventional ways. To wrap up, the students perceived that using mnemonic keyword method was a tool that benefited them in learning and retaining vocabulary better and for a longer time than other traditional ways of learning vocabulary and the mixture of the acoustic and visual elements that are the core of this method is very effective for them.

\section{Discussion}

The findings reveal that the students' attitudes were very positive towards the use of the mnemonic keyword method. These results conform to the results of (Mahdi and Gubeily, 2018; Siegel, 2017; Scruggs and Mastropieri, 1992; Mastropieri et al., 2000). All of them suggest that students are satisfied with the mnemonic keyword method.

They believe that it can be very helpful in retaining vocabulary. This can be attributed to the nature of the keyword method. The keyword method is a two-stage process that has procedures for remembering materials that have an associative element. When learning foreign vocabulary, the learners first must acquire a stable association between the unfamiliar foreign word and a familiar English word that sounds like a salient part of the foreign word. The acoustically similar English word is the keyword. The student then encodes a meaningful interaction between the keyword and the targeted word.

It is apparent that the secret behind the strength of this method in retaining vocabulary is it has a host of associations. The positive attitude from the students can be also attributed to the nature of using bizarre images in teaching vocabulary. This made it more interesting for students to learn as it is unusual and new for them. Their rapport and interpersonal skills increased immensely. Their cooperation with each other also increased especially when discussing with each other. The suspense factor was present as students were anticipating their instructor to show them the bizarre pictures and the similar sound words i.e. keywords. The students' interaction with content was very obvious and that is the ore of active learning. The students perceived that this method is totally different from the traditional methods of explaining new words. They did not feel bored during the lesson and even the low achievers were attentive and participating.

\section{Conclusions}




\section{Macrothink \\ International Journal of English Language Education \\ ISSN 2325-0887 \\ 2019, Vol. 7, No. 2}

\subsection{Pedagogical Implications and Recommendations}

Some important pedagogical implications can be elicited from this research. First, language instructors should utilize images in their teaching as a mnemonic tool with learners in their EFL classrooms. It is recommended that mix this method with technology through designing some online applications that include the targeted words in the students' courses. EFL learners should be motivated to use this method to improve their lexical knowledge.

Due to the gender segregation policy in the kingdom of Saudi Arabia, the researcher could not conduct the study on female students. Only male students participated in the study which may affect the generalizability of this study. It is recommended that for future studies female students should be included in any research which would give a clearer picture of the real situation of the respondents.

In the present study, the researcher tailored and designed the whole program. Some studies trained students to design keywords on their own. It is recommended for future studies to compare and investigate the two studies (a study designed by the teacher and the other designed by the students) to check which method is more efficient and compare their attitudes towards both methods. In fact, as the proverb goes "old is gold", mnemonics, in general, is an old method but is really effective and needs more attention and more consideration when explicating lexical items to EFL students.

\subsection{Conclusion}

The current study investigated the effect of the mnemonic keyword method as a tool to instruct vocabulary. The findings acquired from the experiment showed that learners have very positive attitudes towards the keyword method and its impact on students' retention of vocabulary.

These findings suggest that the main factor that affected the students' attitudes was the use of the mnemonic keyword method. This method gives space to new opportunities for learners to develop and enhance their vocabulary learning. Based on the results of this study, it is concluded that implementing the mnemonic keyword method in vocabulary learning is more effective on students' attitudes than traditional ways of presenting vocabulary. 


\section{References}

Abdul-Razak, M. (2008). The Effectiveness of Keyword Method in Acquisition of Arabic Vocabulary among Students of National Secondary Schools in Malaysia. Unpublished MA Thesis, Islamic University, Malaysia.

Akinsola, M. K., \& Odeyemi, E. O. (2014). Effects of Mnemonic and Prior Knowledge Instructional Strategies on Students Achievement in Mathematics. International Journal of Education and Research, 2(7), 675-688.

Al-Akaby, J. (2013). The impact of keyword strategy on second-year intermediate school female pupils" reading and composition writing (Unpublished Master'sThesis). Bagdad University, Iraq.

Alanazy, M. M. (2013). Participation in online and face-to-face discussions: Perceptions of female Saudi students in the united states (Doctoral dissertation). Retrieved from ProQuest Dissertations and Theses database. (Accession Order No. 3605976).

AlSamadani, H. A., \& Ibnian, S. (2015). The relationship between Saudi EFL students' attitudes towards learning English and their academic achievement. International Journal of Education and Social Science, 2(1), 92-102.

Alsayyali, N. M. (2018). Saudi Arabian Students' Attitudes Toward E-Learning in Select Pennsylvania Universities. The Indiana University of Pennsylvania.

Ali, S. (2015). Effectiveness of the program based on keyword and assembly strategies in the development capacity of the short term in the first-grade middle school in Asyut (Unpublished Master'sThesis). Asyut University, Egypt.

Al-Khawaldeh, M. A., \& Al-Khasawneh, F. M. (2019). The Effect of Mnemonic Keyword Strategy Instruction on Vocabulary Retention of Students with Learning Disabilities. International Journal of English Linguistics, 9(4).

Al-Lahham, I. (2016). The Effectiveness of Using Keyword Based Instruction on Developing Eighth Graders' English Vocabulary and its Retention in Gaza (Master thesis). Islamic University, Gaza, Palestine

Al-Zahrani, M. (2011). The Effectiveness of Keyword-Based Instruction in Enhancing English Vocabulary Achievement and Retention of Intermediate Stage Pupils with Different Working Memory Capacities (Unpublished Master'sThesis). Taif University, Saudi Arabia.

Atkinson, R. C., \& Raugh, M. R. (1975). An application of the mnemonic keyword method to the acquisition of Russian vocabulary. Journal of Experimental Psychology: Human Learning and Memory, 1(2), 126-133.

Bahanshal, D. (2015). The effectiveness of vocabulary learning strategies on English language acquisition of Saudi learners. International Journal of Humanities and Social Sciences, 1(1).

Brazley, M. (2008). The Effects of Mnemonic Keyword and Rote Methods of Vocabulary 
Instruction on the Immediate and Delayed Word Recall and Application by High School Students with Learning Disabilities (Unpublished Master's Thesis). University of Memphis, USA.

Brown, H. D. (2000). Principles of language learning and teaching. 4th ed. White Plains, NY: Addison Wesley Longman.

Brown, T. S., \& Perry, L. (1991). A comparison of three learning strategies for ESL vocabulary acquisition. TESOL Quarterly, (4). 655.

Carney, R. N., \& Levin, J. R. (2000). Mnemonic instruction, with a focus on transfer. Journal of Educational Psychology, 92(4), 783-790.

Carney, R. N., Levin, J. R. \& Stackhouse T. L. (1997). Brief Research Report: The Face-Name Mnemonic Strategy from a Different Perspective. Contemporary Educational Psychology, 22, 399-412.

Carney, R. N., Levin, J. R. (2003). Promoting Higher-Order Learning Benefits By Building Lower Order Mnemonic Connections. Applied Cognitive Psychology, 17, 563-575.

Cohen, A. (1987). The use of verbal and imagery mnemonics in second-language vocabulary learning. Studies in Second Language Learning, 9, 43-62.

Davoudi,M., \& Yousefi, D. (2016). The Effect of Keyword Method on Vocabulary Retention of Senior High School EFL Learners in Iran. Journal of Education and Practice, 7(11), 106-112.

Dianitasari, F. (2019). The effectiveness of Using Mnemonic Keyword on Students' Vocabulary Mastery of the Eighth Grader of MTs Al Ma'arif Tulungagung. A thesis presented to the Faculty of Education and Teacher Training of State Islamic Institute of Tulungagung. Retrieved from: http://repo.iain-tulungagung.ac.id/11580/1/COVER.pdf

Dretzka, B. J., \& Levin, J. R. (1990). Building Factual Knowledge About the U.S. Presidents via Pictorial Mnemonic Strategies. Contemporary Educational Psychology, Vol 15, Issue 2, 152-169.

Edublox. (2017). Simonides of Ceos and the Art and History of Mnemonics. Retrieved from https://www.edubloxsa.co.za/simonides-ceos-art-history-mnemonics

Fasih, P., Izadpanah, S., \& Shahnavaz, A. (2018). The Effect of Mnemonic Vocabulary Instruction on Reading Comprehension of Students. International Journal of Applied Linguistics and English Literature. Volume: 7 Issue: 3 Retrieved from https://www.researchgate.net/publication/324870787_The_Effect_of_Mnemonic_Vocabulary _Instruction_on_Reading_Comprehension_of_Students

Franke, T. M., Levin, J. R., \& Carney, R. N. (1991). Mnemonic artwork-learning strategies: Helping students remember more than "who painted what?". Contemporary Educational Psychology, 16(4), 375-390.

Fulk, B. (2000). Make İnstruction More Memorable. Intervention in School and Clinic, Vol 
35, No 3, 183-184.

Gardner, R. (1985). Social psychology and second language learning. The role of attitudes and motivation.

Gaul, T. A. (2004). Do sixth-grade students have greater immediate recall of vocabulary definitions if they select their own terms while employing the mnemonic keyword method? (Doctoral dissertation, Widener University). Retrieved from https://search.proquest.com/openview/4e8262333e93a77b4049c60a79713bed/1 ?pq-origsite= gscholar\&cbl=18750\&diss $=\mathrm{y}$

https://doi.org/10.20428/JSS.24.1.5

Huong, L. H. (2018). A Survey Study on Academic Vocabulary Learning Strategies by EFL University Students. Journal of Language Teaching and Research, Vol. 9, No. 5, pp. 1009-1016, September 2018 Retrieved from chrome-extension://oemmndcbldboiebfnladdacbdfmadadm/https://pdfs.semanticscholar.org/2 fbc/0c8760c93aff892487123520355355faaa5b.pdf

Kara, A. (2009). The Effect of a „Learning Theories ${ }^{\text {ee }}$ Unit on Students ${ }^{\text {ee }}$ Attitudes towards Learning. Australian Journal of Teacher Education, 34(3), 100-113.

Kayaalt1, M. (2018). Mnemonic Technique-An Effective Vocabulary Teaching Method to Plurilingual Students. Modern Journal of Language Teaching Methods, 8(5), 457-470.

Laufer, B., \& Hill, M. (2000). What lexical information do L2 learners select in a CALL dictionary and how does it affect word retention? Language Learning \& Technology, 3(2), 58 -76 .

Lewis, L., \& Hill, J. (1990). Practical techniques for language teaching. London: Language Teaching Publications.

Lewis, M. (1999). How to study foreign languages. London: Macmillan Press LTD.

M. Tavakoli \& E. Gerami. (2013). The effect of keyword and pictorial methods on EFL learners' vocabulary learning and retention. Porta Liguarum, 19, 299-316.

Mahdi H. S., \& Gubeily M. A. (2018). The Effect of Using Bizarre Images as Mnemonics to Enhance Vocabulary Learning. Journal of Social Studies, Volume 24, Issue (1), March, 2018.

Marzban A., \& Firoozjahantigh M. (2018). The Effect of Mnemonic Keyword Techniques Instruction on Vocabulary Achievement and vocabulary Size of Iranian EFL Learners. International Journal of Applied Linguistics \& English Literature, Volume: 7 Issue: 4 Retrieved from: https://www.researchgate.net/publication/326150366_The_Effect_of_Mnemonic_Keyword_T echniques_Instruction_on_Vocabulary_Achievement_and_vocabulary_Size_of_Iranian_EFL _Learners

Massri, R. (2017). Attitudes of Saudi Foundation Year Students towards Learning English as a Foreign Language: A Qualitative Study (Doctoral dissertation, University of York). 


\section{Macrothink}

International Journal of English Language Education

ISSN 2325-0887

2019, Vol. 7, No. 2

Mastropieri, M. A., \& Scruggs, T. E. (1998). Enhancing School Success with Mnemonic Strategies. Available at: http://www.ldonline.org/article/5912

https://doi.org/10.1177/105345129803300402

Mastropieri, M. A., Spencer, V. G., Scruggs, T. E., \& Talbott, E. (2000). Students with disabilities as tutors: An updated research synthesis. In T. E. Scruggs \& M. A. Mastropieri (Eds.), Advances in learning and behavioral disabilities (Vol. 14, pp. 247- 279). Stamford: JAI Press Inc.

Merry, R. (1980). The keyword method and children's vocabulary learning in the classroom. British Journal of Educational Psychology, 50, 123-136.

Milton, J. (2009). Measuring second language vocabulary acquisition. Bristol, UK: Multilingual Matters.

Moore, J., \& Surber, J. (1992). Effects of context and keyword methods on second language vocabulary acquisition. Contemporary Educational Psychology, 17(3), 286-292.

Olçum, Y. (2000). The Effect of Memory Supporters on Achievement and Retention in Primary School 4th Grade Social Studies Course. Unpublished Ph.D. Thesis. Hacettepe University Institute of Social Sciences.

Ormrod, J. E. (1990). Human Learning (2nd ed.). New Jersey: Prentice-Hall.

Paivio, A. (1991). Dual Coding Theory: Retrospect and Current Status. Canadian Journal of Psychology, 45(3), 255-287.

Paribakht, T. \& Wesche, M. (1999). Reading and "incidental" L2 vocabulary acquisition: An introspective study of lexical inferencing. Studies in Second Language Acquisition, 21, 195-224.

Pressley, G. M., Levin, J. R., \& Delaney, H. D. (1982). The mnemonic keyword method. Review of Educational Research, 52, 61-91. http://dx.doi .org/10.3102/00346543052001061

Pring, R. (2000). Philosophy of educational research. London: Continuum.

Richards, Jack C. (2002). Longman Dictionary of Language Teaching and Applied Linguistics. London; New York: Longman

Rodriguez, M., \& Sadoski, M. (2000). Effects of rote, context, keyword, and context/keyword methods on retention of vocabulary in EFL classrooms. Language Learning, $50(2), 385$

Rummel, N., Levin, J. R., \& Woodward, M. M. (2003). Do Pictorial Mnemonic Text-Learning Aids Give Students Something Worth Writing About? Journal of Educational Psychology, V 95, i 2, p. 327.

Sagarra, N., \& Alba, M. (2006). The key is the keyword: L2 vocabulary learning methods with beginning learners of Spanish. The Modern Language Journal, 90(2), 228-243. 
Sagarra, N., \& Alba, M. (2006). The key is the keyword: L2 vocabulary learning methods with beginning learners of Spanish. The Modern Language Journal, 90(2), 228-243.

Saidat, A, M. (2010). Language Attitude: The Case of Jordan. International Journal of Academic Research, 2, 235-243. [Online] Available: http://www.ijar.lit.az/pdf/8/2010\%286-37\%29.pdf (August 11, 2011)

Schmitt, N. (2000). Vocabulary in language teaching. Cambridge: Cambridge University Press.

Scruggs, T. E., \& Mastropieri, M. A. (1992). Classroom applications of mnemonic instruction: Acquisition, maintenance, and generalization. Exceptional Children, 58, 219-229.

Scruggs, T. E., \& Mastropieri, M. A. (2000). The effectiveness of mnemonic instruction for students with learning and behavior problems: An update and research synthesis. Journal of Behavioral Education, 10, 163-173.

Scruggs, T. E., Mastropieri, M. A. Berkeley, S. L., \& Marshak, L. (2010). Mnemonic Strategies: evidence-based Practice and Practice-Based Evidence. Intervention in School and Clinic, 46(2), 79-86

Senemoglu, N. (1997). Development Learning and Teaching: From Theory to Practice. Ankara: Spot Printing.

Shams, M. (2008). Students' attitudes, motivation and anxiety towards English language learning. Journal of Research, 2(2), 121-144.

Siegel, L. (2017). The effectiveness of the mnemonic keyword strategy on math vocabulary learning for students with learning disabilities. Theses and Dissertations. 2420. Retrieved from: https://rdw.rowan.edu/etd/2420

Sikes, P. (2004). Chapter 2 Methodology Procedures and Ethical Concerns, in Opie, C. (ed.). (2004). Doing Educational Research. London: Sage.

Snape, D., \& Spencer, L. (2003). The Foundation of Qualitative Research. In J. Ritchie and J. Lewis. (Eds.). Qualitative Research Practice: A Guide for Social Science Students and Researchers. London: SAGE Publications. 1-23.

Stephens, J. A. H., \& Dwyer, F. M. (1997). Effect of Varied Mnemonic Strategies İn Facilitating Student Achievement of Different Educational Objectives. Internatioal Journal of Instructional Media, 24, 1; Proquest Educational Journals pg.75.

Uberti, H. Z., Scruggs, T. E., \& Mastropierri, M. A. (2003). Keywords Make the Difference: Mnemonic Instruction in inclusive Classrooms. TEACHING Exceptional Children, Vol. 35, No.3, 56-61.

Ummah, H., Maryadi, M.A and, Mauly H. H. (2018). The Effect Of Mnemonic Keyword Method On Students' Vocabulary Mastery Viewed From Students' Creativity (An Experimental Study at the Seventh Grade Students of SMP Dharma Lestari Salatiga in the Academic Year 2018/2019). MA Thesis, University of Muhammadiyah Surakarta, Indonesia. 


\section{Macrothink}

Retrieved from: http://eprints.ums.ac.id/69280/

Vlasceanu, M. (2018). Mnemonic Influence: How Memory Impacts Emotion, Reason, and Action (Master's Thesis, Princeton University). Retrieved from: https://scholar.princeton.edu/sites/default/files/madalinavlasceanu/files/mnemonic_influence. pdf

Walonick, D. S. (1993). Organizational theory and behavior, viewed 09 July 2015, from http://www.statpac.org/walonick/organizational-theory.htm

Wilson, E., \& Stutchbury, K. (2009). Chapter 4 - Research Design and Ethics, in Wilson, E. (2009). School-Based Research A Guide For Education Students. London: Sage.

Winne PH., \& Marx R.W. (1989). A cognitive-processing analysis of motivation within classroom tasks. In: C. Ames, Ames R (eds.) Research on motivation in education: Vol. 3. Goals and cognitions San Diego: Academic Press, Inc. pp. 223-257.

Zarei, Abbas \& Ramezankhani Ma, Zeinalabedin. (2018). The Comparative Effects of Mnemonic Keyword Method, Storytelling, and Semantic Organization on L2 Idiom Learning. Teaching English Language Journal. Article 2, Volume 12, Issue 1, Winter and Spring 2018, Page 31-60. Retrieved from http://www.teljournal.org/article_58549.html 
Appendices

\section{Appendix A}

The Questionnaire that shows students' attitudes towards the Keyword Method

\begin{tabular}{|l|l|l|l|l|l|}
\hline Statement & $\begin{array}{l}\text { Strongly } \\
\text { Agree }\end{array}$ & Agree & neutral & disagree & $\begin{array}{l}\text { Strongly } \\
\text { disagree }\end{array}$ \\
\hline $\begin{array}{l}\text { 1- I am not happy with my current } \\
\text { position of vocabulary. }\end{array}$ & & & & \\
\hline $\begin{array}{l}\text { 2- I think that my vocabulary can be } \\
\text { improved after using other different } \\
\text { strategies. }\end{array}$ & & & & \\
\hline $\begin{array}{l}\text { 3- I think that vocabulary instruction in } \\
\text { class should be considered in a better } \\
\text { way in the future. }\end{array}$ & & & & & \\
\hline $\begin{array}{l}\text { 4- I am not happy with my current } \\
\text { level of English vocabulary. }\end{array}$ & & & & & \\
\hline $\begin{array}{l}\text { 5- I think using mnemonics through } \\
\text { linking the pictures with the vocabulary } \\
\text { can improve my vocabulary. }\end{array}$ & & & & & \\
\hline $\begin{array}{l}\text { 6- I find myself focusing more on the } \\
\text { vocabulary that is associated with the } \\
\text { pictures that are more unusual. }\end{array}$ & & & & & \\
\hline $\begin{array}{l}\text { 7- Associating pictures with vocabulary } \\
\text { in class made me more excited to learn } \\
\text { vocabulary }\end{array}$ & & & & & \\
\hline $\begin{array}{l}\text { 8-Using the keyword method helps me } \\
\text { recall vocabulary than other } \\
\text { conventional methods. }\end{array}$ & & & & & \\
\hline
\end{tabular}

\section{Acknowledgement}

The researchers financed this research out of great their pedagogical interest in this topic. Thanks to Taibah University (TU) and Al-Madinah International University (MEDIU).

\section{Copyright Disclaimer}

Copyright for this article is retained by the author(s), with first publication rights granted to the journal.

This is an open-access article distributed under the terms and conditions of the Creative Commons Attribution license (http://creativecommons.org/licenses/by/3.0/). 